\title{
Micro, Small and Medium Enterprises (MSMEs) in India: The Engine of Growth
}

\author{
B.B. Sahoo ${ }^{1}$ and K.C. Swain ${ }^{*}$ \\ ${ }^{1}$ Deputy General Manager in NABARD and Faculty Member in Bankers Institute of Rural Development (BIRD), Bolpur, West Bengal, \\ India \\ ${ }^{2}$ Department of Agricultural Engineering, Institute of Agriculture, Visva-Bharati, Sriniketan, West Bengal, India
}

*Corresponding author: kishore.swain@visva-bharati.ac.in

Received: 22-09-2019

Revised: $20-01-2020$

Accepted: 24-02-2020

\begin{abstract}
With rising cost of crop cultivation, narrowing margin, fast increasing family expenditure and rising unemployment, agriculture may not succeed in offering meaningful living to millions of farmers in rural India. Seeing the growing contribution of Micro, Small and Medium Enterprises (MSMEs) in increasing employment and income of the people, it is felt that MSME sector may supplement farmers' income and help rural India to achieve equity and promote a balanced economic development. The MSMEs also support in industrializing rural areas. Growth of the sector in the last few decades is quite encouraging. But these enterprises are facing many bottlenecks such as infrastructure, demand, quality raw material, manpower with skill and credit facility. This article attempts to study the growth, importance and key challenges of the MSME sector in India. The article concludes with a statement that MSMEs are the lower layer of the enterprise system, which contributes to the overall GDP and welfare by generating additional employment, increasing export and maintaining equity. Therefore, MSMEs must be explored and made use of as a powerful tool of growth and social justice.
\end{abstract}

Keywords: MSMEs, Growth, Employment, Agri-business, Challenges, Margin

India is primarily an agrarian country with around 60 percent of its people depending directly or indirectly upon agriculture. But poverty and unemployment prevails all over the country due to declining per capita farm land, thin gap between income and expenditure and increasing uncertainty in crop cultivation. Although agriculture sector is the biggest employer in the country, the contribution of MSME sector to the overall GDP is more than agriculture. After agriculture, MSME is the biggest employer. Over the last few decades, the sector has emerged as a vibrant and dynamic sector. This sector has been assuming special importance for its role in ensuring income equality, employment generation, poverty reduction and promoting a balanced economic development in the country.

\section{BOX I}

\section{MSME Sector at a Glance 2014-18}

* MSMEs provide large employment opportunities at lower capital cost than large industries

* India's MSME sector comprises of 633.88 lakh units as per National Sample Survey $73^{\text {rd }}$ Round (2015-16)

* MSME sector has created about 11.10 Crore jobs in the country

* Products: produces more than 6000 products.

Sources: msme.gov.in. 
With inelastic supply of land and rising population, agriculture alone may not succeed in generating enough employment avenues to sustain the rural work force. Creation of employment opportunities is one of the best means of inclusive growth and MSMEs, after agriculture, have the largest employment potential in rural areas. In countries like Japan, Germany and the USA, the MSME sector has done wonders in achieving economic development and bridging the gap between the rich and the poor. Understanding the importance of MSMEs, Government of India has been taking various initiatives for encouraging farmers, artisans, businessmen to become entrepreneurs. Over the last few decades, the sector has emerged as a vibrant and dynamic sector. Therefore, there is an urgent need to boost efforts to expand employment opportunities through labour intensive rural industries and allied activities. The article attempts to study the growth, importance and key challenges of the MSME sector in India.

\section{Definition of Micro, Small \& Medium Enterprises}

In accordance with the provisions of Micro, Small \& Medium Enterprises Development (MSMED) Act, 2006, the MSMEs are classified into two classes, i.e., Manufacturing enterprises and Service enterprises (MSMED, 2006). This classification is based on investment made in plant and machineries, if they are operating in the manufacturing sector, and investment in equipment, for service sector enterprises (Ministry of Law and Justice, 2006).

Manufacturing Enterprises: The enterprises involved in the manufacture or production of goods pertaining to any industry mentioned in the first schedule to the industries (Development and regulation) Act, 1951) or employing plant and machinery in the system of value addition to the final product having a distinct name or character or use. The Manufacturing Enterprise is defined in terms of total investment in Plant \& Machinery.

Service Enterprises: The enterprises engaged in providing or rendering of services are defined in terms of investment in equipment. Table 1 presents the details of investments in plant and machinery in Manufacturing and Services enterprises.

Table 1: Investments in plant \& machinery in Manufacturing and Service Enterprises

\begin{tabular}{|c|c|c|}
\hline Enterprise & $\begin{array}{l}\text { Manufacturing } \\
\text { Enterprises }\end{array}$ & Services Enterprises \\
\hline Micro & Up to ₹ 25 lakh & Up to ₹ 10 lakh \\
\hline Small & $\begin{array}{l}\text { Above } ₹ 25 \text { lakh up to } ₹ \\
5 \text { Crore }\end{array}$ & $\begin{array}{l}\text { Above ₹ } 10 \text { lakh up to ₹ } \\
2 \text { Crore }\end{array}$ \\
\hline Medium & $\begin{array}{l}\text { Above ₹ } 5 \text { Crore up to ₹ } \\
10 \text { Crore }\end{array}$ & $\begin{array}{l}\text { Above ₹ } 2 \text { Crore up to ₹ } \\
5 \text { Crore }\end{array}$ \\
\hline
\end{tabular}

\section{BOX II}

\section{Government's proposal for change in the definition of MSMEs}

On 07 February 2018, the Union cabinet approved a proposal to redefine MSMEs based on their annual revenue, replacing the current definition that relies on self-declared investment on plant and machinery. Accordingly, businesses with revenue of as much as ₹ 5 crore will be classified a micro enterprise, those with sales between ₹ 5 crore and ₹ 75 crore will be entitled as small and those with revenue between ₹ 75 crore and ₹ 250 crore will be deemed as medium-sized enterprises. The Micro, Small and Medium Enterprises Development (MSMED) Act, 2006 will be amended to define units producing goods and rendering services in terms of annual turnover.

Table: Classification of MSMEs

\begin{tabular}{|c|c|c|}
\hline Classification of the MSME & New Classification (Annual turnover) & Old classification* (Investment in Plant \& Machinery) \\
\hline Micro & Not exceeding ₹ 5 crores & Below ₹ 25 lakhs \\
\hline Small & Between $₹ 5$ crores to $₹ 75$ crores & $₹ 25$ lakhs to $₹ 5$ crores \\
\hline Medium & $₹ 75$ to $₹ 250$ crores & $₹ 5$ crores to $₹ 10$ crores \\
\hline \multicolumn{3}{|c|}{$\begin{array}{l}\text { Further, the Union Budget announced a cut in corporate tax from } 30 \text { percent to } 25 \text { percent to stimulate the MSME sector's growth. To give an impetus } \\
\text { to MSME sector growth, the Central Bank of the country has also decided to give a longer period to small businesses before classifying their loans as } \\
\text { non-performing assets or bad loans. The Reserve Bank of India raised the repayment period of MSME loans from } 90 \text { days to } 180 \text { days for classification } \\
\text { as bad loans or NPA (Parmar, 2018). The change in definition is expected to improve business and avoid unnecessary inspections and enable authorities } \\
\text { to verify claims of business using GST network sales data. }\end{array}$} \\
\hline
\end{tabular}




\section{Contribution of the MSMEs}

The Micro, Small \& Medium Enterprises (MSMEs) have been contributing immensely to the expansion of entrepreneurial endeavours through business innovations. The MSMEs are widening their domain across various sectors by producing diverse range of products and services to meet domestic as well as global markets. This sector occupies a key place in terms of output, exports and employment created in the country. It produces about 45 percent of manufacturing output and 40 percent of the total exports. Furthermore, about 110.99 million persons are engaged in MSME units in over 63.39 million units throughout the country. It plays a very important role in industrializing rural areas and thereby reducing regional imbalances (Patel, 2017).

As per the data available with Central Statistical Office (CSO), Ministry of Statistics \& Programme Implementation, the contribution of MSME Sector in country's Gross Value Added (GVA) ${ }^{1}$ and Gross Domestic Product (GDP) ${ }^{2}$, at current prices for the last five years is given in Table 2 .

Table 2: Contribution of MSMEs in Country's Economy at Current Price (Amount in ₹ Lakh)

\begin{tabular}{llllll}
\hline Year & $\begin{array}{l}\text { MSME } \\
\text { GVA }\end{array}$ & $\begin{array}{l}\text { Total } \\
\text { GVA }\end{array}$ & $\begin{array}{l}\text { Share of } \\
\text { MSME in } \\
\text { GVA (\%) }\end{array}$ & $\begin{array}{l}\text { Total } \\
\text { GDP }\end{array}$ & $\begin{array}{l}\text { Share of } \\
\text { MSME in } \\
\text { GDP (\%) }\end{array}$ \\
\hline $2011-12$ & 2583263 & 8106946 & 31.86 & 8736329 & 29.57 \\
$2012-13$ & 2977623 & 9202692 & 32.36 & 9944013 & 29.94 \\
$2013-14$ & 3343009 & 10363153 & 32.26 & 11233522 & 29.76 \\
$2014-15$ & 3658196 & 11481794 & 31.86 & 12445128 & 29.39 \\
$2015-16$ & 3936788 & 12458642 & 31.60 & 13682035 & 28.77 \\
\hline
\end{tabular}

Source: Central Statistical Office (CSO), Ministry of Statistics $\mathcal{E}$ Programme Implementation, Government of India.

It is evident from the table that Gross Value Added in MSME, which was ₹ 2583263 lakh in 2011-12, increased to ₹ 3936788 lakh in $2015-16$ at 52.4 percent. The share of

\footnotetext{
${ }^{1}$ Gross Value Added (GVA): Estimates of GVA had been prepared at factor cost in the earlier series with base year 2004-05, while they are prepared at basic prices in the new series of 2011-12. GVA estimated by production approach: (GVA $=$ Output - Material Inputs) and GVA estimated by income approach: (GVA = Compensation of Employees + Operating Surplus + CFC).

${ }^{2}$ Gross Domestic Product (GDP): GDP is derived by adding taxes on products, net of subsidies on products, to GVA at basic prices.
}

MSME in total Gross Value Added remained consistent at above 31 percent during the last five years. During the year 2015-16, the share of MSME in total Gross Domestic Product was 28.8 percent. The contribution of Manufacturing MSMEs in India's total Manufacturing GVO (Gross Value of Output) at current prices has remained nearly consistent at around 33\%, i.e., onethird during the last five years (Annual Report, 2017). The MSME sector in India has performed well in terms of size, level of technology employed, range of products and services provided and target markets. For instance, the number of working enterprises, which was 36.18 million in 2006-07, increased by 75.2 percent and became 63.39 million enterprises in 2015-16. Similarly, the number of persons engaged in MSMEs increased by 37.8 percent from 80.52 million in $2006-07$ to 110.99 million in 2015-16.

\section{NSS $73^{\text {rd }}$ Round Survey (2015-16) \& MSMEs}

As per the National Sample Survey (NSS) 73rd round conducted during the period 2015-16, MSME sector has created 11.10 crore jobs (360.41 lakh in Manufacturing, 387.18 lakh in Trade and 362.82 lakh in Other Services and 0.07 lakh in Non-captive Electricity Generation and Transmission) in the rural and the urban areas across the country. Further, the Micro sector with 630.52 lakh estimated enterprises accounts for more than $99 \%$ of total estimated number of MSMEs. Thus, tiny units represent a great majority (Annual Report, 2017). Any policy measures directed to improve the productivity of such a large number of units, and enhance the skills of persons/artisans engaged in these activities will no doubt make a major contribution to our objective of uplifting the living standards of rural poor. The major findings of the Survey 2015-16 were as under:

Estimated No. of MSMEs in the country: During the period 2015-16, there were 633.88 lakh unincorporated non-agriculture MSMEs in the country engaged in different economic activities (196.64 lakh in Manufacturing, 230.35 lakh in Trade, 206.84 lakh in Other Services and 0.03 lakh in Non-captive Electricity Generation and Transmission, ) excluding the MSMEs registered under (a) Sections $2 \mathrm{~m}$ (i) and $2 \mathrm{~m}$ (ii) of the Factories Act, 1948, (b) Companies Act, 1956 and 
(c) Construction activities falling under Section F of National Industrial Classification (NIC) 2008.

Table 3: Distribution of estimated MSMEs by nature of activity

\begin{tabular}{|c|c|c|c|}
\hline $\begin{array}{l}\text { Activity } \\
\text { category }\end{array}$ & $\begin{array}{l}\text { No. of } \\
\text { Enterprises } \\
\text { (Lakh No.) }\end{array}$ & \begin{tabular}{|c|} 
Other \\
Services \\
$33 \%$ \\
\end{tabular} & $\begin{array}{c}\text { Manufact } \\
\text { uring } \\
31 \%\end{array}$ \\
\hline Manufacturing & 196.65 & & \\
\hline Trade & 230.35 & & \\
\hline Other Services & 206.88 & & Trade \\
\hline Total & 633.88 & & $36 \%$ \\
\hline
\end{tabular}

Source: Annual Report, MSME 2017-18.

Activity-wise distribution of the MSMEs: 31\% MSMEs were found to be engaged in manufacturing activities, while 36\% were in Trade and 33\% in Other Services. Again out of 633.88 lakh estimated number of MSMEs, 324.88 lakh MSMEs (51.25\%) were in rural area and 309 lakh MSMEs (48.75\%) were in the urban areas.

Sector-wise distribution of MSMEs: The Micro sector with 630.52 lakh estimated enterprises contributes more than $99 \%$ of total estimated number of MSMEs. Small sector with 3.31 lakh and Medium sector with 0.05 lakh estimated MSMEs accounts for nearly $0.52 \%$ and $0.01 \%$ of total estimated MSMEs, respectively.

State-wise distribution of MSMEs: State of Uttar Pradesh had the largest number of estimated MSMEs with a share of $14.20 \%$ of MSMEs in the country. West Bengal comes close to second with a share of $14 \%$ again. The top ten states, i.e., Uttar Pradesh, West Bengal, Tamil Nadu, Karnataka, Maharashtra, Bihar, Andhra Pradesh, Gujarat, Rajasthan and Madhya Pradesh, together accounted for a share of $74.05 \%$ of the total estimated number of MSMEs in the country (Annual Report, 2015). The top 10 States also nearly 70 percent of the total employment generated within the MSME establishments. The distribution of establishments in rural and urban areas is unequally distributed (Table 4).

Employment status in MSMEs: During the period 2015-16, MSME sector has been generating 11.10 crore jobs (360.41 lakh in Manufacturing, 387.18 lakh in Trade and 362.82 lakh in Other Services and 0.07 lakh of Non- captive Electricity Generation and Transmission) in the rural and the urban areas across the country.

Gender-wise employment in MSMEs: Out of 1109.89 lakh employees in MSME sector, 844.68 lakh employees $(76 \%)$ are male employees and remaining 264.92 lakh $(24 \%)$ are females.

Table 4: Top 10 States in terms of number of MSME establishments

\begin{tabular}{llll}
\hline Rank & Name of the State & $\begin{array}{l}\text { Number of } \\
\text { establishments } \\
\text { (No. in Lakh) }\end{array}$ & $\begin{array}{l}\text { Share in } \\
\text { Total (\%) }\end{array}$ \\
\hline 1 & Uttar Pradesh & 89.99 & 14.2 \\
2 & West Bengal & 88.67 & 14.0 \\
3 & Tamil Nadu & 49.48 & 7.8 \\
4 & Maharashtra & 47.78 & 7.5 \\
5 & Karnataka & 38.34 & 6.0 \\
6 & Bihar & 34.46 & 5.4 \\
7 & Andhra Pradesh & 33.87 & 5.3 \\
8 & Gujarat & 33.16 & 5.2 \\
9 & Rajasthan & 26.87 & 4.2 \\
10 & Madhya Pradesh & 26.74 & 4.2 \\
\hline & All India & $\mathbf{6 3 3 . 8 8}$ & $\mathbf{1 0 0 . 0}$ \\
\hline
\end{tabular}

Source: Annual Report, MSME 2017-18.

With gradual improvement in the economic well being, the demand for items of common use is on the rise and will generate vast markets in rural areas. Besides, nontraditional activities such as welding, grinding, cutting, polishing units, assembling units, packaging, testing auto/electric/electronic repairs, quality checks, toys making, hand-made paper, handicrafts, agro-processing activities, etc., have a vast potential in rural areas. The maintenance and service units for agro-implements, electric appliances, television and radio, heaters, stoves, pump-sets, wood-polishing, furniture/cart making etc., also have great scope. Of late, the demand for a number of service sector activities like restaurants, hotels, dhabas, PCOs, Internet Cafes etc., has also increased. Financing self-employed persons is equally a potential area in the non-farm sector. Banks may play a crucial role in locating potential activities for financing in $\mathrm{CO}^{-}$ ordination with the other agencies. 


\section{Ministry of Micro, Small \& Medium Enterprises and MSME Sector}

The Ministry of Micro, Small \& Medium Enterprises envisions a progressive MSME sector by promoting growth and development of the Sector, including Khadi, Village and Coir Industries, in cooperation with concerned Ministries/Departments, State Governments and other Stakeholders, by providing support to existing enterprises, adopting cutting-edge technologies and encouraging creation of new enterprises. A number of statutory and non-statutory bodies which working under the aegis of Ministry of MSME. These generally include the Khadi Village Industries Commission (KVIC) and the Coir Board besides The National Small Industries Corporation (NSIC), National Institute for Micro, Small and Medium Enterprises (NIMSME) and also Mahatma Gandhi Institute for Rural Industrialisation (MGIRI). The Ministry runs various schemes aimed at financial assistance, technology assistance and upgradation, infrastructure development, skill development and training, enhancing competitiveness and market assistance of MSMEs. On 9 May 2007, the erstwhile Ministry of Small Scale Industries and Ministry of Agro and Rural Industries were merged to form the Ministry of Micro, Small and Medium Enterprises. The Ministry designs policies, facilitates programmes/ projects proposals and monitors their implementation, with a view to assisting MSMEs and helping them to scale up. The major sectors covered under MSMEs are explained below (Annual Report, 2017):

\section{Khadi \& Village Industries (KVI)}

Khadi and Village Industries (KVI) programmes are implemented through 34 State/Union Territories (UTs) Khadi and Village Industries Boards (KVIBs); 4601 registered institutions and Banks/Financial institutions. The Khadi programme is implemented through institutions registered either with KVIC or State/UT KVIBs. In India, khadi activity/sector is considered as potential tool for creation of employment opportunities at the doorstep of rural artisans at very low capital investment. Immediately after independence, Khadi and Village Industries became the grand symbol of nationalism. As such, Khadi came to be known not just as a piece of cloth, but as a symbol of freedom and selfreliance. There is a total of 2,375 khadi institutions in the country that employ a total of 4,56,000 artisans. The majority of khadi institutes are situated in the Central part of the country. Table 5 presents the details of the trends in sale of different khadi products.

Table 5: Trends in sale of different khadi products (Amount in ₹ Crore)

\begin{tabular}{llll}
\hline Year & Cotton & Woolen & Silk \\
\hline $2013-14$ & 672.74 & 187.87 & 220.43 \\
$2014-15$ & 714.39 & 204.15 & 251.83 \\
$2015-16$ & 936.20 & 256.70 & 317.10 \\
$2016-17$ & 1159.20 & 332.10 & 516.31 \\
\hline
\end{tabular}

Source: Annual Report, MSME, Various Issues.

\section{Village Industries}

Village industries have shown consistent growth over the past many years. Village industries includes around seven different sectors such as Agro-based \& Food Processing Industry (ABFPI), Polymer \& Chemical Based Industry (PCBI), Forest Based Industry (FBI), Hand Made Paper \& Fibre Industry (HMPFI), Rural Engineering \& Bio Technology Industry (REBTI) and SEP/Service Industry. Production of village industries increased from ₹ 21135.06 crores in 2011-12 to ₹ 41110.26 crore in 2016-17 at an annual growth rate of 14.0 percent. Similarly, sales of goods produced by village industries increased at an annual rate of 13.6 percent from 201112 to 2016-17. Table 6 presents the details of production and sale of village industries from 2011-12 to 2016-17.

Table 6: Production and Sale of Village Industries (₹ Crore)

\begin{tabular}{lll}
\hline Year & Production & Sale \\
\hline $2011-12$ & 21135.06 & 25829.26 \\
$2012-13$ & 23262.31 & 26818.13 \\
$2013-14$ & 25298.00 & 30073.16 \\
$2014-15$ & 26689.39 & 31965.52 \\
$2015-16$ & 33424.62 & 40384.56 \\
$2016-17$ & 41110.26 & 49991.61 \\
\hline
\end{tabular}

Source: Annual Report, MSME, Various Issues. 


\section{Coir Industry}

Coir industry is an agro-based traditional industry, which originated in the State of Kerala and proliferated to the other coconut producing States like Tamil Nadu, Karnataka, Andhra Pradesh, Odisha, West Bengal and Maharashtra. It is an export-oriented industry having very high potential to enhance exports through technological interventions and value addition. Coir is a coarse fibre extracted from the husk, the fibrous outer shell of coconut. Ropes and cordage, made out of coconut fibre have been used from ancient times. Indian navigators, who sailed the seas to Malaya, Java, China and to the Gulf of Arabia centuries ago, had been using coir as their ships' cables. The coir manufacturing industries generally produce coir mats, matting and other floor coverings, were started in India on factory basis, over a hundred and fifty years ago when the first factory was set up in Alleppey in 1859 (Unnithan, 1970).

The Ministry has been attaching importance to the development of coir sector in the country. The production of coir fibre was around 3,25,900 MT up to end of 2017 and the cumulative employment for 7.29 lakh persons against the fibre production of 5,56,900 MT during the previous financial year. The estimated production of coir and coir products during the last two years are presented in Table 7.

Table 7: Trends in production of coir products (Quantity in MT)

\begin{tabular}{lll}
\hline Item & $\mathbf{2 0 1 5 - 1 6}$ & $\mathbf{2 0 1 6 - 1 7}$ \\
\hline Coir fibre & 549300 & 556900 \\
Coir yarn & 329600 & 334200 \\
Coir products & 217500 & 220500 \\
Coir rope & 65920 & 66850 \\
Curled coir & 65850 & 66800 \\
Rubberized coir & 87900 & 89100 \\
\hline
\end{tabular}

Source: Annual Report, MSME, Various Issues.

India is one of the important countries in coir fibre production and export. It supplies about 55 percent of the total white coir fibre in the world. The details of India's export of coir during the last six years are presented in Table 8. It may be observed from the table that the value of exports increased from ₹ 1052.60 lakh in 2011-12 (Coir Board, 2011) to ₹ 228164.82 lakh in 201617 at an annual growth rate of more than 125 percent. It is pertinent to observe here that the value of exports of coir products, which was ₹ 256.20 per Metric Ton (MT) in 2011-12, decreased to ₹ 238.41per MT in 2016-17.

Table 8: Trends in export of coir during last five years

\begin{tabular}{lll}
\hline Year & Quantity (MT) & Value (₹ Lakh) \\
\hline $2011-12$ & 410854 & 1052.62 \\
$2012-13$ & 429501.00 & 111603.00 \\
$2013-14$ & 537040.38 & 147603.84 \\
$2014-15$ & 626666.00 & 163033.77 \\
$2015-16$ & 752020.00 & 190142.52 \\
$2016-17$ & 957045.00 & 228164.82 \\
\hline
\end{tabular}

Source: Annual Report, MSME, Various Issues.

Many countries import coir products from India. Among all the importing countries, China stands first, followed by the USA in terms of import of coir products from India. The other countries who import coir products from India are the Netherlands, the United Kingdom and South Korea. Table 9 presents the top five coir importing countries from India.

Table 9: Top five coir importing countries and their imports

\begin{tabular}{|c|c|c|c|c|c|}
\hline \multirow{2}{*}{$\begin{array}{l}\text { Sl } \\
\text { No }\end{array}$} & \multirow{2}{*}{ Country } & \multicolumn{2}{|c|}{ Physical quantity } & \multicolumn{2}{|c|}{ Value of the imports } \\
\hline & & $\begin{array}{l}\text { Metric } \\
\text { Tonnes }\end{array}$ & $\begin{array}{l}\text { Percentage } \\
(\%)\end{array}$ & ₹ Lakh & $\begin{array}{l}\text { Percentage } \\
(\%)\end{array}$ \\
\hline 1 & China & 439884.57 & 46.0 & 66655.52 & 29.2 \\
\hline 2 & USA & 133536.72 & 13.9 & 53286.56 & 23.3 \\
\hline 3 & $\begin{array}{l}\text { The } \\
\text { Netherlands }\end{array}$ & 82487.53 & 8.6 & 18148.78 & 7.9 \\
\hline 4 & $\begin{array}{l}\text { The United } \\
\text { Kingdom }\end{array}$ & 17668.15 & 1.8 & 11076.22 & 4.8 \\
\hline 5 & South Korea & 57545.12 & 6.0 & 9486.28 & 4.2 \\
\hline
\end{tabular}

Source: Annual Report, MSME, 2017-18.

A snapshot of select Schemes of the Ministry of MSME is given below: 


\section{BOX III}

Govt of India launches support and outreach initiative for greater synergy to MSME sector

1. Loans up to ₹ 1 crore within 59 minutes through online portal

2. Interest subvention of $2 \%$ for all GST registered MSMEs on fresh or incremental loans

3. All companies with a turnover of more than ₹ 500 crores to be mandatorily on TReDS platform to enable entrepreneurs to access credit from bank, based on their upcoming receivables, thus, solving the problems of cash cycle.

4. All PSUs to compulsorily procure 25 percent from MSMEs instead of $20 \%$ of their total purchases.

5. Out of the $25 \%$ procurement mandated from MSMEs, $3 \%$ reserved for women entrepreneurs

6. All CPSUs to compulsorily procure through GeM Portal

7. 109 Technology Centres to be established at the cost of ₹ 6000 crore

8. Government of India to bear $70 \%$ of the cost for establishing

9. Returns under 8 labour laws and 10 Union Regulations to be filed once in a year

10. Establishment to be visited by an Inspector will be decided through a computerized random allotment

11. Single consent under air and water pollution laws: Returns will be accepted through self-certification and only 10 percent MSME ends to be inspected.

12. For minor violations under the Companies Act, entrepreneurs no longer have to approach court but can correct them through simple procedures.

\section{Government's Initiatives for promotion of the} MSMEs

The Government has been taking a number of steps for promoting development of MSMEs. It has provided MUDRA and Stand Up India for meaningful intervention in small and medium enterprises. The Ministry of MSME runs numerous schemes targeted at (a) providing credit and financial assistances (b) skill development training, (c) infrastructure development, (d) marketing assistance, (e) technological and quality upgradation and (f) Other Services for development of the MSMEs across the country. The 12 initiatives taken by the Government of India for MSME sector is as under (Skill Development, 2014).

\section{Make in India}

Hon'ble Prime Minister, in his Independence Day speech on August 15, 2014, introduced "Make in India", to facilitate investment, foster innovation, enhance skill development, protect intellectual property and build best in class manufacturing infrastructure in the country. This initiative is based on four pillars such as New Processes, New Infrastructure, New Sectors and New Mindset, which have been identified to give boost to entrepreneurship in India, not only in manufacturing but also other sectors (Sanyal and Jaipuria, 2014).

The main objective of this new programme is to attract investments from across the globe and strengthen India's manufacturing sector. The programme is being led by the Ministry of Commerce and Industry of Government of India. It also aims at utilizing Indian talents, creating additional employment opportunities and empowering secondary and tertiary sectors. The programme also intends to attract the investors and businessmen all over the world to come and manufacture in India. The focus of Make in India programme is on 25 sectors, which include automobiles, aviation, chemicals, pharmaceuticals, construction, electrical machinery, food processing, textiles and garments, ports, mining, tourism and hospitality, railways, renewable energy, biotechnology, space, etc. One of the major indicator of progress is the unprecedented opening up of key sectors - including Defence, Railways, Insurance and Medical Devices - to dramatically higher levels of Foreign Direct Investment (Sanyal and Jaipuria, 2014).

\section{Prime Minister Employment Generation Programme (PMEGP)}

The scheme aims to generate employment opportunities in rural as well as urban areas through setting up of new self-employment ventures/ projects/ micro enterprises. The second objective is to provide continuous and sustainable employment to a large segment of traditional and prospective artisans and rural / urban unemployed youth in the country, so as to help reduce migration of rural youth to urban areas. A third objective is to increase the wage earning capacity of artisans and contribute to increase in the growth rate of rural and urban employment (PMEGP, 
2008). The Scheme is implemented by KVIC, as the nodal agency at the National level. At the State level, the Scheme is implemented and monitored by State KVIC Directorates, State Khadi and Village Industries Boards (KVIBs) and District Industries Centres (DICs) and banks. The maximum cost of the project per unit admissible under manufacturing sector is around ₹ 25 lakh and under service sector is around ₹ 10 lakh.

\section{Intended beneficiaries}

Any individual, above 18 years of age is eligible to seek assistance. If the project size is above ₹ 10 lakh in the manufacturing sector and above ₹ 5 lakh in the business / service sector, the applicant must be at least Class VIII qualified. Only new projects with balanced estimation are considered for sanction under PMEGP. Self-Help Groups (SHG, including those belonging to BPL provided that they have not availed benefits under any other Scheme), Institutions registered under Societies Registration Act, 1860; Production Cooperative Societies, and Charitable Trusts etc. are also eligible.

\section{Credit Linked Capital Subsidy Scheme (CLCSS)}

The objective of the Scheme namely "Credit Linked Capital Subsidy Scheme (CLCSS)" for Technology Upgradation of Micro and Small Enterprises is to facilitate technology up-gradation in Micro and Small Enterprises (MSEs) by providing capital subsidy of $15 \%$ (under ₹ 15.00 lakhs) on institutional finance availed by them for induction of well-established and advanced technology (Agenda paper, 2018). Maximum limit of eligible loan for calculation of subsidy under the Scheme is investment in approved plant \& machinery up to ₹ 1.00 crore for induction of well-established and improved technologies. The CLCSS is envisaged to address investment needs of the MSE units, awareness creation of quality standards and access to modern technologies, etc. Presently, 51 Sectors / sub-sectors with approved Machinery/Technologies are covered under the scheme. The scheme is applicable to new and existing Micro \& Small Enterprises (MSEs) engaged in manufacturing sector (Mishra, 2015).

Office of the Development Commissioner (MSME) is implementing the scheme through 12 Nodal Banks/
Agencies. The eligible MSEs are required to apply online through Primary Lending Institutions (PLIs), from where the MSEs availed term loan for up-gradation of technology. The completed application is uploaded by PLI through Online Application and Tracking System to the attached Nodal Agency, which, in turn, recommends the application online to Office of DC (MSME) for release of subsidy. After processing of application and subject to availability of funds, due approval is accorded from competent authority and concurrence of Internal Finance Wing, after which funds are released to Nodal Agencies (Agenda paper, 2018). Funds are then transferred by the Nodal Agencies to the PLIs where the account of the MSE is operated.

The scheme has been immensely successful in enabling MSEs in technology up-gradation. This in turn has resulted in productivity improvement, increase in turn over and productivity. A substantial enhancement in product quality has also been found. The scheme has also led to energy reduction in terms of electricity consumption and fuel consumption besides having a positive impact on air, water and noise pollution. Since, inception of the scheme 48,618 MSEs have availed subsidy which is ₹ 2907.68 crore by end of 2017 (Annual Report, 2017).

\section{Credit Guarantee Trust Fund for MSEs (CGTMSE) - Provision of collateral credit for MSMEs}

Guarantees are provided for extending collateral free lending to Micro and Small Enterprises through banks and financial institutions (including NBFCs). The Scheme covers collateral free credit facility (term loan or working capital) extended by eligible lending institutions to new and existing micro and small enterprises up to ₹ 200 lakh per borrowing unit. The guarantee cover provided is around $75 \%$ of the credit facility up to ₹ 50 lakh provided to micro enterprises, $80 \%$ for MSEs owner by women and all loans to NER) with a uniform guarantee at $50 \%$ of the credit exposure above ₹ 50 lakh and up to ₹ 200 lakh. A composite all in Annual Guarantee Fee of around 1.0\% p.a. of the credit facility sanctioned (around $0.75 \%$ for credit facility up to ₹ 5 lakh and $0.85 \%$ for above ₹ 5 lakh and up to 200 lakh for women owner, Micro Enterprises and units in NER including Sikkim) is charged. 
Credit Guarantee Scheme has been set up to strengthen credit delivery system and to enable flow of credit to the sector by facilitating loan to the tune of ₹ 2 crore without collateral or third-party guarantee. Government of India is now fully contributing to the corpus of CGTMSE. Consequent to approval of the proposal of Ministry of MSME on 'Package for supporting Micro and Small Enterprises (MSEs)', Government had approved the augmentation of the corpus of the Trust from ₹ 2,500 crore to ₹ 7,500 crore in December 2016. The increase of the corpus by ₹ 5,000 crore was entirely contributed by Government of India. Non-Banking Finance companies (NBFCs) have also been under the Credit Guarantee Scheme for disbursing loans being extended to micro and small enterprises (Muthuselvan, 2018).

This Scheme has covered more than 29 lakh beneficiaries in last 10 years. The beneficiaries experienced a boost in their turnover as well as employment generation in the years following approval of CGTMSE funding. CGTMSE funding has had a positive impact on six major areas in the MSE sector - technology upgradation, skill upgradation, market development, sustainability of scheme, economic impact, and social Impact. The scheme has been successful in spanning itself geographically across the country with a special focus in the North East. The benefits of the scheme have also reached more than 100 industrial sectors in which MSEs are operating. CGTMSE has been highly effective in settling the claims wherein the first installment was settled within 3 weeks in majority of the cases. As on 31st December, 2017, cumulatively $29,68,859$ proposals have been approved for guarantee cover for a total sanctioned loan amount of ₹ 1,41,878.14 crore (Musthafa, 2017).

\section{Scheme for promotion of Innovation, Rural Industry and Entrepreneurship (ASPIRE)}

The Ministry has introduced a new scheme named ASPIRE, in March 2015. The main objectives of the scheme are to create new jobs and reduce unemployment, promote entrepreneurship culture and grassroot economic development and promote innovation to strengthen the competitiveness of MSME sector. A total of 100 Livelihood Business Incubators (LBIs) and 20 Technology Business Incubators (TBIs) are envisaged to be set up. Till 31st March 2018, 62 LBIs have been approved of which, 33 commenced incubation. Out of 17,000 incubatees who have completed incubation, 30 percent have set up their own enterprises or engaged in productive employment. Further, 8 TBIs have been approved and 55 compelling ideas have been received from these TBIs. The 'Fund of Funds' has been enhanced to ₹ 310 crore and as on 31.3.2018, an amount of ₹ 100 crore has been released to SIDBI for investment in startups in agro-based industries (Mishra, 2015).

\section{Revival and Rehabilitation Framework under MSMEs}

Ministry of MSME, in 2015, notified a 'Framework for Revival and Rehabilitation of MSMEs' so as to provide for a simpler and faster mechanism to address the stress in the MSME accounts. RBI issued guidelines to Banks on $17^{\text {th }}$ March 2016, wherein Banks were asked to create a structure by 30th June 2016 for approval of Corrective Action Plan for MSMEs. Banks has been taken in 95,107 cases (with backlog cases) by the Committee under the framework by September, 2017.

\section{Scheme of Fund for Regeneration of Traditional Industries (SFURTI)}

The objectives of the scheme are to organize traditional industries and artisans into clusters to make them competitive and provide support for their long term sustainability, sustained employment, to enhance marketability of products of such clusters, to equip traditional artisans of the associated clusters with the improved skills, to make provision for common facilities and improved tools and equipment for artisans, to strengthen the cluster governance systems with the active participation of the stakeholders, and to build up innovative products, improved technologies, advanced processes, market intelligence and new models of public-private partnerships. The scheme covers three types of interventions (Mishra, 2015):

* Soft interventions - Activities to build general counselling, awareness, skill enhancement and capacity building, exposure visits, market development initiatives, design and product development, etc. 
* Hard interventions - Creation of common facility centres, raw material banks, upgradation of production infrastructure, warehousing facility, tools and technological upgradation, etc.

* Thematic interventions - Interventions on a crosscutting basis for brand building, new media marketing, e-commerce initiatives, research and development, etc.

The financial assistance provided for any specific project shall be subject to a maximum of ₹ 8.0 crore to support Soft, Hard and Thematic interventions. The MSME Ministry has constituted a Scheme Steering Committee as the apex coordination and monitoring body. The KVIC, Coir Board, NiMSME (Hyderabad), IED (Odisha), IIE (Guwahati), IMED, J\&K KVIB are the Nodal Agencies for scheme implementation in their respective areas. Additionally, other Nodal Agencies are being recorded for implementation.

Intended beneficiaries: Non-Government organizations (NGOs), institutions of the Central and State Governments and semi-Government institutions, field functionaries of State and Central Govt., Panchayati Raj institutions (PRIs), Private sectors by forming cluster specific SPVs, Corporate and Corporate Responsibility (CSR) system foundations with expertise to undertake cluster development.

\section{Scheme for Micro \& Small Enterprises Cluster Development Programme (MSE - CDP)}

Ministry has adopted the cluster development approach as a key strategy for enhancing the productivity and competitiveness as well as capacity building of Micro and Small Enterprises (MSEs) and their collectives in the country.

The objectives of the scheme are to support the sustainability and growth of MSEs by addressing common issues such as improvement of technology, skills and quality, market access, access to capital etc, to build capacity of MSEs for common supportive action through formation of self-help groups, consortia, upgradation of association etc., and also to create / upgrade infrastructural facilities in the existing/new industrial areas or clusters of MSEs (MSE-CDP, 2018).

\section{Schemes providing financial assistance to Khadi institutions with MPDA}

Government has introduced with effect from 01.04.2010, a flexible, growth stimulating and artisan oriented Market Development Assistance (MDA) Scheme, in place of the erstwhile system of Rebate. Under MDA, financial assistance is provided to institutions @ 20\% of the value of production of khadi and polyvastra, to be shared among artisans, producing institutions and selling institutions in the ratio 40:40:20. MDA provides institutions basic flexibility to support the assistance for improving the outlets, products and production processes, besides giving direct incentive to customers, etc (MPDA, 2016). The scheme has been modified as MPDA by amalgamating existing Market Development Assistance on production (Khadi \& Poly) Scheme and additional components of Publicity, Marketing and Market promotion \& Infrastructure (inclusive of new component of Marketing Complexes/Khadi Plaza) out of VI Grant. Under the Modified MDA (MMDA), Pricing may be fully delinked from the cost chart and products can be sold at market-linked prices at all stages of production. Incentives would be extended to Artisans, Karyakartas and support groups.

Additionally, production \& marketing support for products, which found self-sustainable, will be phased out. Modified MDA shall be calculated at around thirty percent of the Prime Cost, \{including the cost of raw material plus conversion charges up to grey cloth plus processing charges without margins\}. The Modified MDA shall be distributed amongst producing institutions (40\%), seller institutions $(20 \%)$ and the artisans (40\%). The KVIC can act as the implementing agency. Intended beneficiaries: The Khadi institutions, having valid Khadi Certificate and categorized as A+, A, $\mathrm{B}, \mathrm{C}$, are only eligible to avail MDA grant from KVIC (MPDA, 2016).

\section{Financial support to MSMEs in ZED Certification}

The Ministry of Micro, Small \& Medium Enterprises (MSME), Government of India has launched on 18.10.2016 a new scheme 'Financial Support to MSMEs in ZED Certification Scheme', for the benefit of Micro, Small \& Medium Enterprises (MSMEs). The scheme 
will be implemented in 22,222 MSMEs with the total Project Cost of ₹ 491.00 crore. The scheme envisages promotion of Zero Defect and Zero Effect (ZED) manufacturing amongst MSMEs and ZED Assessment for their certification with the objectives like, developing an Ecosystem for Zero Defect manufacturing in MSMEs, promoting adaption of Quality tools/systems and Energy Efficient manufacturing, enabling MSMEs for manufacture of quality products and to encourage MSMEs to upgrade the quality standards in products, processes and systems with adoption of Zero Defect production system and without impacting the environment, etc.

Till $1^{\text {st }}$ February 2018, 10,963 MSMEs are registered under ZED certification. 5129 MSMEs started Online Self-Assessment system, 1424 have already completed in six months. 242 MSMEs have paid Fees for Desk Top Assessment and 60 MSMEs have paid their Fees for Site Assessment. Out of 38 cases presented before Rating Committee 08 MSMEs given Gold, 14 MSMEs given Silver, 09 MSMEs given Bronze and 07 MSMEs have no rating (Annual Report, 2017).

\section{Challenges before MSME sector}

In spite of the big contribution of the MSMEs in India's growth story, the sector is facing challenges. The general problems faced by the sector are as under: Poor infrastructure base including technology, Inadequate capital and technical know-how, Low production capacity, Ineffective marketing strategy, Constraints in modernization and expansion, Non-availability of skilled labour at affordable cost etc.

In particular, the challenges faced by the sector may slightly vary. For instance, the main challenges in Khadi industry are the following: Competition from handloom, mill made, branded ethnic segment and also from duplicate products, Cash on the opportunity of developing market-oriented products, Improvement of skill, production of market-driven consumers' demand, Modernization of equipment, infrastructure and operations etc.

Similarly, although the Indian Coir continues to enjoy its supremacy in the world market, the products of this industry are facing tough competition from other cheaper products. Being manufactured from an agricultural produce with a relatively high level of costs of inputs, coir goods are dearer than synthetics and other competing items. The method of production and processing of coir, in many parts of the country, continues to be obsolete. Modernization of the Coir Industry with state-of-art production techniques, machinery etc., is the need of the hour. Even though there is stiff competition for coir in the area of floor covering material, products like Coir Pith, Coir Geo-Textile, and Coir Wood offers a plethora of opportunities in the developing world. Bringing coir products under the 'Eco-Mark' and environment-friendly goods category would be ideal step in this direction. Coir products being 100 percent eco-friendly and bio-degradable offers solution to the current day serious issues like deforestation, global warming etc. (Kaur and Sarin, 2017).

Indian market is growing at faster rate and Indian entrepreneurs are also making remarkable progress in various Industries like Manufacturing, Precision Engineering Design, Food Processing, Textile \& Garments, Pharmaceutical, Retail, IT and ITES, Agro and Service sectors. Therefore, it is very much required to educate, empower and train the workforce the latest developments in the field so that they can compete with global giants.

\section{Limitations in promoting MSMEs}

Some of the crucial constraints faced by the rural entrepreneurs in promoting MSME sector are indicated below:

* Most of the MSME units are based on traditional skills. Therefore, technological up-gradation and innovations in production techniques have largely remained ineffective.

* These units rely on local raw materials whose supply is generally erratic, often seasonal and in many cases exploitatively controlled by middlemen. This results in increased cost of production and uncertainties in operations.

* Capital investment is low, but there is no guarantee that increase in capital base would increase in 
production. Other factors of production need to be taken into consideration.

* Price of the commodity depends on supply and demand. As a result, entrepreneurs do not have control or say over the prices of products. Demand for the product gets affected adversely due to inadequate communication, quality of the product and substitutes. As a result, the rural entrepreneurs fail in the face of competition from organised sector.

* Lack of infrastructural facilities has been a major bottleneck for the entrepreneurs.

* There is a lack of improved tools and technologies in these enterprises. As a result, the entrepreneurs are forced to continue with outdated techniques of production.

* Marketing continues to be one of the most important and formidable bottlenecks. The mechanism of market information, awareness creation and demand-supply situation hinder their forward growth.

\section{Approach for popularizing MSMEs}

As mentioned earlier, the problems of MSMEs are numerous and complex. Their nature and intensity are very wide. No single policy framework or package of strategies can provide an answer to their multifarious problems and constraints. A multi-agency approach may be adopted in the matters of financing, promoting and providing direction to such enterprises. The strategies must have to take into account the need to introduce and popularise improved tools and technical innovations wherever possible to improve the quality of products and their competitiveness (Nath and Singh, 2010).

Technology infusion is another important player in reducing time, cost and labour and increasing output. The majority of our MSME units use traditional mode of production. Upgradation of technology and achieving economies of scale is one of the major problems facing the MSME sector. With a view to foster the growth of MSME sector in the country, government has taken up several initiatives such as ISO Certification Fee Reimbursement Scheme, National Manufacturing Competitiveness
Programme and various other initiatives to enhance technology options in MSMEs.

\section{CONCLUSION}

Most of the MSME solutions are responses to social problems, and therefore, in a growing economy like ours, opportunities in MSMEs must be explored and made use of as a powerful tool of growth and social justice. The second important aspect is that MSMEs are the lower layer of the enterprise system and they help the economy by generating additional employment, increasing export and contribution to GDP. Further, it forms the social base of the enterprise economy of India. Thus, MSME sector is crucial to India's progress.

The country has significant potential in MSME sector, but for meaningful exploitation and growth of the sector, critical gaps relating to knowledge, infrastructure, governance and skill must be plugged in. Harnessing the potential of MSMEs would be both opportunities and challenges. Of late, technology is having a revolutionary impact in many fields. With global competition, the MSMEs must incorporate latest technology in every aspect of their operation such as financing, production, marketing and management to withstand the pressure and they must also be innovative and competitive.

\section{SUMMARY}

The Micro, Small and Medium Enterprises (MSMEs) is capable to increase employment and income of the people. It is also felt that MSME sector may supplement farmers' income and help rural India to achieve equity and promote a balanced economic development. The MSMEs also support in industrializing rural areas. But these enterprises are facing bottlenecks, such as lack of proper infrastructure, demand, quality of raw material, manpower with skill and credit facility. This article attempts to study the growth, importance and key challenges of the MSME sector in India. MSMEs are the lower layer of the enterprise system, which contributes to the overall GDP and welfare by generating additional employment, increasing export and maintaining equity. 


\section{REFERENCES}

Agenda Papers. 2018. Agenda Papers for $16^{\text {th }}$ Meeting of National Board for Micro, Small \& Medium Enterprises, held on $26^{\text {th }}$ February, 2018, pp. 1-27.

Annual Report. 2017. Annual report, Micro, Small and Medium Enterprises (MSME) sector, Government of India.https:// msme.gov.in/sites/default/files/MSME-AR-2017-18-Eng.pdf.

Annual Report. 2015. Annual report, Micro, Small and Medium Enterprises (MSME) sector, Government of India.https:// msme.gov.in/sites/default/files/MSME-AR-2015-16-Eng.pdf.

CGTMSE. 2010. Credit Guarantee Fund Scheme for Micro And Small Enterprises, pp.1-3. https://msme.gov.in.

Chaudhary, H.P. 2017. ZED Scheme for MSMEs, Business Standard. https://www.business- standard.com.

Coir Board. 2011. Coir Board Annual Report 2011-12, pp.77.

Kaur, N. and Sarin, V. 2017. Comparative advantages and competitiveness of Indian agricultural products exports to asean in context of India's look east policy. Int. J. Agricult. Stat. Sci., 13(1): 159-167.

Mishra, K. 2015. New Initiatives of MSME Ministry: Aspire Scheme Launched to Promote Rural Entrepreneurship. http:// pib.nic.in/newsite/PrintRelease.aspx?relid=133532.

MPDA. 2016. Market Promotion and Development Assistance Scheme, MPDA Guidelines, Directorate of Khadi, pp.1-28. http://www.kvic.org.in.

MSE-CDP. 2018. Micro \& Small Enterprises Cluster Development Programme, pp.1-21. http://www.msmedildh.gov.in.
MSMED. 2006. Ministry of Law and Justice, 2006. Micro, Small \& Medium Enterprises Development (MSMED) Act, 2006, No. 27 of 2006, The Gazette of India. https:// samadhaan.msme.gov.in/WriteReadData/DocumentFile/ MSMED2006act.pdf

Musthafa, M. 2017. CGTMSE: Credit Guarantee Trust Fund for MSEs Report. www.cgtmse.in/about_us.aspx.

Muthuselvan, E.R. 2018. Innovative Credit Products for MSME sector and to evaluate the Credit Guarantee Mechanism under CGTMSE and compare with Credit Guarantee Mechanism of Japan, IIBF Diamond Jubilee and C H Bhabha Banking Overseas Project report, pp.1-127.

Nath, R. and Singh, G. 2010. Creating Competitive SMEs. Confederation of Indian Industry, pp. 1-30. http://www.cii.in.

Parmar, B. 2018. RBI's relief for MSMEs: Loans up to ₹ $25 \mathrm{cr}$ will now be classified as NPAs after 180 days. www.moneycontrol. com.

Patel, D. 2017. Importance of MSME sector in India. Business. http://www.iamwire.com.

Skill Development. 2014. Skill development by Ministry Of Micro, Small \& Medium Enterprises 2014-15, Published by Government of India, pp. 68.

PMEGP. 2008. Prime Minister's Employment Generation Programme (PMEGP), KVIC report, pp. 1-21. http://www. kvic.org.in.

Sanyal, S. and Jaipuria, S. 2014. Make in India: Bolstering Manufacturing Sector. Published by PHD Chamber of Commerce and Industry, New Delhi, pp.32.

Unnithan, K.B. 1970. Coir Industry in India with Special Reference to Marketing and Trade. Coir Board Report, Cochin, P.2. 
